\title{
DESTAQUES
}

\section{CONGRESSO NACIONAL DE DIREITO PENAL E CIÊNCIAS AFINS}

Realizou-se em São Paulo, de 9 a 15 de fevereiro de 1975, o. V Congresso Nacional de Direito Penal e Ciências Afins, patrocinado pelo Governo do Estado através das Secretarias da Justiça e da. Cultura e da Faculdade de Direito do Largo São Francisco. A coordenação esteve a cargo do Prof. MANOEL PEDRO PIMENTEL e a participação, representando o Departamento de Direito Penal e Processual Penal da Universidade Federal do Paraná, dos Professores ALCIDES MUNHOZ NETTO, ATHOS MORAES DE CASTRO VELLOZO, FERNANDO NEWTON BITTENCOURT FOWLER, RENE ARIEL DOTTI e LUIZ ALBERTO MACHADO. Os dois últimos apresentaram teses quie, aprovadas, se transformaram em conclusões do Congresso. A saudação inicial aos Congressistas foi feita pelo Prof. ALCIDES MUNHOZ NETTO.

O V Congreso Nacional de Direito Penal e Ciências Afins chegou às seguintes conclusões:

"1. O grau de periculosidade aferido obrigatoriamente pelo juiz, na sentença, consoante a legislação penal proposta, ainda que possa ser revisto no curso da execução da pena é de transcendental relevância, pois indicará o tipo de estabelecimento penal a que o sentenciado deverá ser recolhido, ligando-se, diretamente, com a of:cialização da prisão-albergue, além do "sursis" em regime de penas.

2. Tendo em vista os dispositivos da legislação penal brasileira proposta, que estabelece a aferição da periculosidade mediante exame criminológico, deve tal exame: ser feito, na medida do possível, por especialistas aptos para definir a capacidade criminológica e o grau de adaptação social do delinquente.

3. ${ }^{a}$ Deve ser mantida a aplicação da pena por tempo relativamente indeterminado, quanto ao mínimo, e somente às categorias dos criminosios häbifuais e por tendência. 
4. ${ }^{a}$ Reexame parcial do conceito de criminoso habitual, principalmente no que tange à habitualidade presumida que, na forma da legislação penal proposta, constitui uma presunção de culpabilidade.

5. ${ }^{a}$ Reexame do conceito de criminoso por tendência, que deveria ser melhor explicitado.

6. A pena deve assentar-se no requisito da culpa, de sorte que, ao ser aplicada, surge como retribuição ética da conduta. No curso da execução, porém, deve ser acrescido um sentido de readaptação.

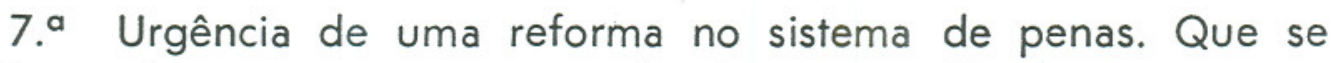
fortaleça a luta que se vem empenhando, no sentido de que a pena de prisão se restrinja a delinquentes que representam um perigo social, ou aos casos de comprovada necessidade, encontrando-se para os outros tipos de infratores substitutivos penais satisfatórios.

8. ${ }^{a}$ Nos casos de infrações passíveis de penas leves, e, ademais, sendo o agente primário, sem periculosidade e tiver reparado - dano, é de conveniência possa o juiz encerrar o processo após a instrução, reconhecendo a perempção.

9. ${ }^{-}$Independentemente da vigência do novo Código Penal, adoção em todos os Estados do Brasil do regime de "prisão-albergue", quer através de lei estadual, quer através de provimentos dos órgãos competentes das Magistraturas estaduais, pois a concessão do trabalho externo em obras públicas ou entidades privadas nada mais é do que a execução da pena através de laborterapia.

10. $\mathrm{Na}$ parte geral da legislação repressiva proposta devem figurar dispositivos regulamentando a possibilidade de perdão judicial, considerando-o causa de extinção da periculosidade, subordinado a determinadas condições subjetivas e objetivas.

11. a A legislação penal proposta deverá admitir, como já o faz o vigente Código Penal Militar, a renovação do "sursis" quando a infração anterior não revelar má indole do agente. Ficaria assim redigido um dispositivo:

A execução de pena privativa de liberdade, não superior a dois anos, pode ser suspensa por dois a seis anos, se o condenado não tiver sofrido condenação anterior por infração penal reveladora de má indole, for de escassa ou nenhuma periculosidade e tiver demonstrado o sincero desejo de reparar o dano.

12. Aquele que comete novo crime 5 anos após a extinção 
ou cumprimento da pena por crime anterior tem direito a postular o sursis, graças à prescrição da reincidência em todos os seus efeitos.

13. ${ }^{a}$ Necessidade de um Código de Execuções Penais dirigindo e orientando toda a política penitenciária do País, objetivando-se que não fiquem à mercê de deficiências da administração aqueles que estão privados de liberdade (reservado, é claro, aos Estados, o direito de elaborar normas supletivas).

14. ${ }^{a}$ Reformulação do sistema de execução das penas, modernizando o ultrapassado regime penitenciário brasileiro, com fundamento na realidade do País e nas necessidades do momento, atinando-se para os novos conceitos de execução penal no mundo moderno.

15. A execução da pena deve ser feita sob um sistema interacionista, dinâmica e que garanta maiores poderes ao Juiz na indivi. dualização concreta da pena, com efetiva fiscalização jurisdicional e que proteja todos os direitos da pessoa humana não atingidos pela sanção.

16. A duração da pena pode ser reduzida na fase de execução por força da prevenção especial, corrigindo-se os erros de valorização do grau de desadaptação do condenado, não ficando o juízo da execução adstrito ao grau mínimo.

17. No atual momento histórico brasileiro, devem ser eliminadas as expressões "reclusão", "detenção" e "prisão simples", substituídas pela expressão "prisão".

18. ' É conveniente a substituição das expressões "velho"; "enfermiço" ou "enfermo" e "criança" contidas na legislação penal proposta, pela fórmula genérica: crime cometido contra quem tenha sua capacidade de defesa de qualquer forma reduzida.

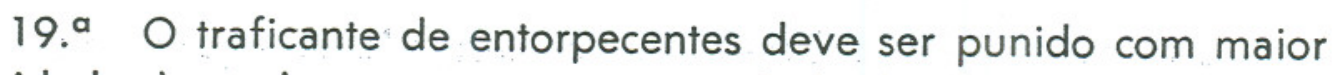
severidade, levando-se em conta a nocividade da droga e a extensão do tráfico". 